\title{
Optimization of Straight-bladed Darrieus type vertical axis wind blade for low wind speed
}

\author{
Christian M. Mortel ${ }^{1,2^{*}}$, Nicanor L. Serrano ${ }^{3}$, and John Gabriel G. Decena ${ }^{4}$ \\ ${ }^{1}$ Graduate Programs, Technological Institute of the Philippines, Quezon City, 1109, Philippines. \\ ${ }^{2}$ Mechanical Engineering, Romblon State University, Odiongan, Romblon, 5505, Philippines. \\ ${ }^{3}$ Mechanical Engineering, Technological Institute of the Philippines, Manila, 1001, Philippines. \\ ${ }^{4}$ Aeronautical Engineering, FEATI University, Manila, 1001, Philippines.
}

\begin{abstract}
Straight-bladed Darrieus blade is a type of vertical axis wind turbine that requires low wind speed to operate but is considered less efficient due to conventional blade geometry. To increase its performance by means of dynamic torque, the study used a statistical method, central composite design, through DesignExpert software. The computational fluid dynamics (CFD) through SolidWorks Reynolds-Averaged Navier Stokes Equation (RANS) $\mathrm{k}$ - epsilon turbulence model was used to simulate the Design of Experiments. The study was composed of two phases, namely 2D and 3D simulations. The 2D simulation studied the effect of varying the camber, camber location, and thickness to the dynamic torque, while the $3 \mathrm{D}$ simulation varied the blade height, rotor radius, and materials. The camber's optimal conditions, camber location, and thickness in 2D simulations are $4.75 \%, 45 \%$, and $15.50 \%$ of the chord, respectively. These optimal design values could reach the dynamic torque equivalent to 60.6571 Newton-meter. Meanwhile, the blade height and rotor radius of the 3D simulations have optimal design values of 4.41 meters and 4.75 meters, respectively. These optimal values could increase the dynamic torque to 2310.01 Newton-meter. The dynamic torque of the optimal design obtained a $133 \%$ significant increase compared to the conventional blade. Thus, the research has proven the increase in the Darrieus Wind turbine's performance by varying its blade geometry.
\end{abstract}

\section{Introduction}

As stated by the International Energy Agency (IEA), the world is heavily dependent on non-renewable energy sources for its energy consumption [1]. The main problem behind the advantages of these energy sources was that they were not sustainable and created global warming due to greenhouse gases hazardous to the environment [2]. Because of these rising environmental pollutions, increasing demand for energy, and diminishing nonrenewable resources, renewable energy resources focus on research and development [3]. Many countries aimed to rely $100 \%$ on renewable energy. The Philippines has the potential

*Corresponding author: xtian_mortelrme@yahoo.com 
areas for wind energy extraction [4]. This could probably be harnessed through existing wind turbine machines.

Due to the advantage of wind energy over other resources in terms of cost, more wind energy extraction researches were greatly focused [3]. Interest in the use of wind has been growing over the past years because of its advantage. Wind energy plays a major role in the production of electricity.

Wind turbines convert the kinetic energy of atmospheric air into mechanical energy. The two forms of wind turbines are the Horizontal Axis Wind Turbine (HAWT) and the Vertical Axis Wind Turbine (VAWT). Vertical axis wind turbines become a capable technology in energy production for sustainable development. It has immense opportunities for several applications in urban economic areas, and isolated sites. Other uses [5] VAWTs can harness wind energy even at low speeds at a relatively lower noise than HAWTs [6].

According to the aerodynamic forces, the two types of VAWTS are lift-type devices and drag-type devices. The Savonius VAWTs are the later kinds that are the most typical. It comprised of two or three scoops and looked like a two-scoop machine with an S-form cross-section when viewed down. Drag-type devices harness much less wind energy than lift-type turbines of a similar scale [7, 3]. The most typical lift type devices are the Darrieus VAWTs. They are possibly representing large-scale VAWTs used in the recent wind energy industry because of their higher power coefficient [8]. As compared to Savonius, Darrieus rotors are high-energy conversion efficiency turbines but low self-starting capability [9]. Studies proved that the Darrieus type of wind turbine is more efficient than the Savonius type turbine.

Different research studies were conducted for straight bladed Darrieus small-scale wind turbines to improve its performance in terms of power and torque coefficient. The blade geometry of the airfoil affects the the power and efficiency of the blade [10]. The airfoil parts are the leading edge radius, camber, leading edge, chord line, thickness, mean camber line, and trailing edge.

Most studies vary in the parts of the blade geometry. This was because the blade profile plays a pivotal role in the energy absorption of wind. However, most researchers only compare the different design values without considering their interactions in each factor. With this, the optimal design of each factor was not achieved. Thus, this study answered these gaps. It focused on varying the camber, camber location, thickness, blade height, and rotor radius, and materials of the airfoil. These were quantitatively assessed to their effect and interaction to the performance in terms of dynamic torque NACA airfoils following a methodical CFD analysis VAWT. The result's accuracy was also dependent on the governing equation (RANS: K-Epsilon) of the Solidworks solver, and the refinement level depends on the computer's computing capacity. The study was limited only to the identified factors in 2D and 3D analyses. Therefore, other factors that may affect the performance of the straight-bladed Darrieus type of turbine were not considered.

\section{Method}

Figure 1 shows the flow chart of optimizing the Darrieus wind turbine. It started by selecting the factors that will affect the turbine's dynamic torque based on the different studies conducted. The study has two parts, which are the 2D and 3D simulations. The 2D investigation factors are the camber, camber location, and thickness during rotor radius and blade height for the 3D simulation. The study used the central composite design (CCD) of the Design Expert to optimize the Darrieus Wind Turbine dynamic. Using the ReynoldsAveraged Navier Stokes Equation (RANS), k - epsilon model of Solidworks software, the factors' combination runs were simulated to identify their dynamic torques. These torques 
were encoded in the Design-Expert software to determine the optimum design values that will generate the high possible or optimum torque.

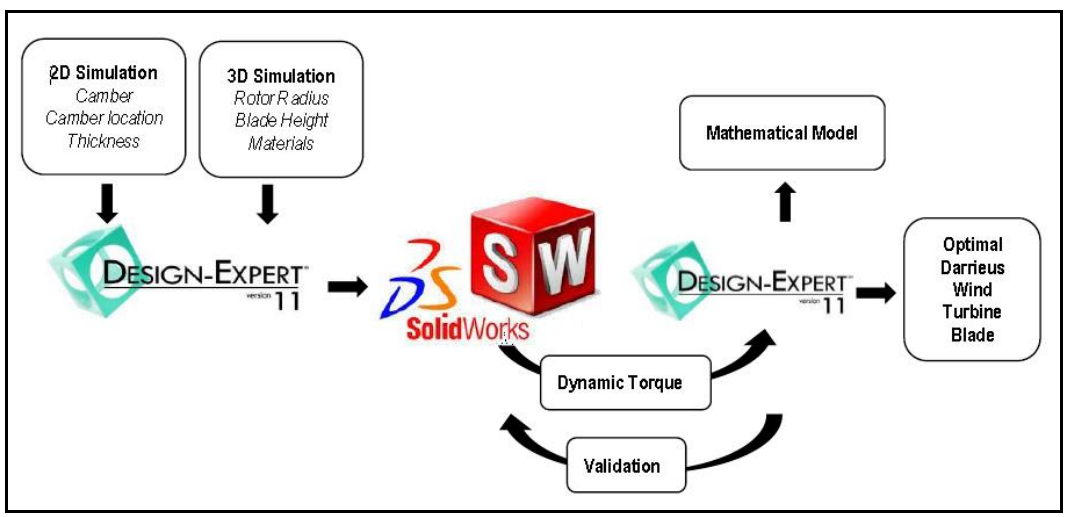

Fig. 1. Flow chart of optimisation.

Table 1. Design of Experiment Setup for 2D Simulation.

\begin{tabular}{|l|c|c|c|c|c|}
\hline Factors & $-\boldsymbol{\alpha}$ & $\mathbf{- 1}$ & $\mathbf{0}$ & $\mathbf{+ 1}$ & $+\boldsymbol{\alpha}$ \\
\hline Camber (\%) (0-9.5) & 0.00 & 1.93 & 4.75 & 7.57 & 9.50 \\
\hline Camber Location (\%) (20-70) & 20.00 & 30.13 & 45.00 & 59.87 & 70 \\
\hline Thickness(\%) (5 - 26) & 5.00 & 9.26 & 15.50 & 21.74 & 26.00 \\
\hline
\end{tabular}

Following the CCD setup, Table 1 showed the three factors with five corresponding levels. The CCD is composed of factorial $\left(2^{\mathrm{k}}\right)$, start points $(2 k)$, and center point ( $n_{c}$ varies), where $\mathrm{k}$ is the number of factors. Based on the formula, this setup has 20 experimental runs, presented in Table 3. Table 2 showed the two factors with five levels. Using CCD, this will generate 13 experimental runs or design of experiments.

Table 2. Design of Experiment Setup for 3D Simulation.

\begin{tabular}{|l|c|c|c|c|c|}
\hline Factors & $-\boldsymbol{\alpha}$ & $\mathbf{- 1}$ & $\mathbf{0}$ & $\mathbf{+ 1}$ & $+\boldsymbol{\alpha}$ \\
\hline Blade Height & 1.000 & 1.586 & 3.000 & 4.414 & 5.000 \\
\hline Rotor Radius & 1.333 & 1.919 & 3.333 & 4.747 & 5.333 \\
\hline
\end{tabular}




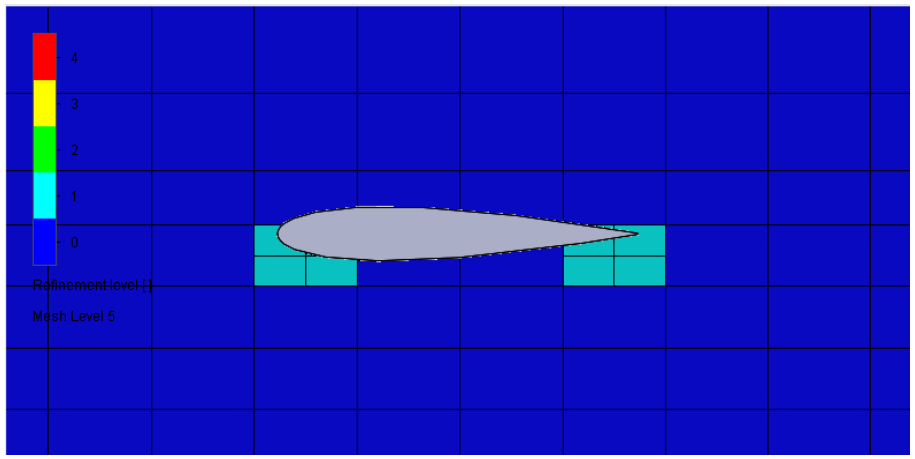

Fig. 2. Mesh five (5) of the replicated computation domain.

The figure above is a finite volume mesh of the fluid boundary subdivided into multiple cells. It used a finite volume method in which the fluid properties (normal and parallel forces) per cell are computed iteratively and summed up to get the total value. It can be noticed that the leading edge has smaller sized cells as the curvature in these areas is greater. These smaller cells are necessary to produce more accurate results. The best results with the lower computational time required are achieved at Mesh level 5. It has 4, 011 cells and had undergone 800 iterations and 20 passes. The boundary condition used was at the sea level.

\subsection{Evaluation}

The validation was done by performing three simulations on the optimal design, averaging its results, and comparing it with the optimal. The equation below was used to compute the accuracy of the result:

\section{Results and discussion}

\subsection{D optimization of blade geometry}

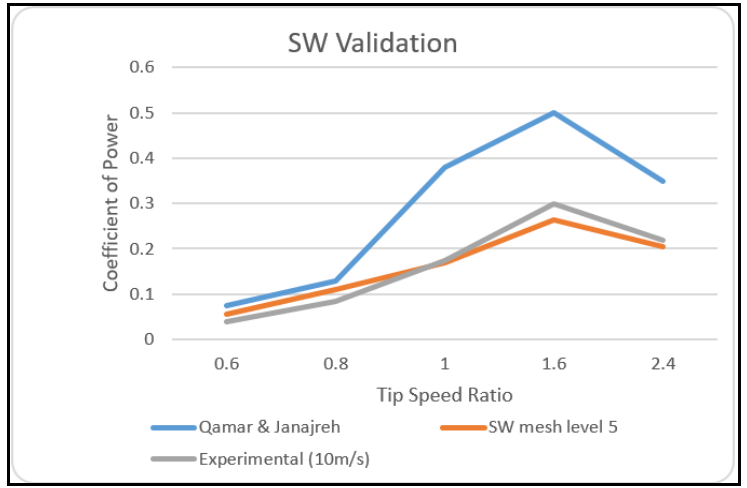

Fig. 3. Validation of flow simulation comparison. 
The replicated computational domain, mesh 5, was validated based on the experimental setup and study of Qamar and Janajreh (2017). Figure 3 represents the coefficient of performance vs. Tip Speed Ratio of NACA 0015 Airfoil. It can be seen that the Solidworks mesh level 5 has a close trend to that of the experimental setup.

Table 3. Results of 2D simulation.

\begin{tabular}{|c|c|c|c|c|c|}
\hline \multicolumn{5}{|c|}{ Factors } & \multirow{2}{*}{$\begin{array}{c}\text { Response } \\
\begin{array}{c}\text { Dynamic Torque } \\
\text { (N-M) }\end{array} \\
\end{array}$} \\
\hline Std & Run & $\begin{array}{c}A-\underset{(\%)}{\text { Camber }} \\
(\%)\end{array}$ & $\begin{array}{c}\text { B - Camber } \\
\text { Location (\%) }\end{array}$ & $\begin{array}{c}\text { C - Thickness } \\
(\%)\end{array}$ & \\
\hline 7 & 1 & 1.93 & 59.87 & 21.74 & 39.5171 \\
\hline 12 & 2 & 4.75 & 70.00 & 15.50 & 45.0717 \\
\hline 18 & 3 & 4.75 & 45.00 & 15.50 & 60.4886 \\
\hline 3 & 4 & 1.93 & 59.87 & 9.26 & 10.1312 \\
\hline 10 & 5 & 9.50 & 45.00 & 15.50 & 9.855 \\
\hline 19 & 6 & 4.75 & 45.00 & 15.50 & 60.4886 \\
\hline 1 & 7 & 1.93 & 30.13 & 9.26 & 9.4045 \\
\hline 9 & 8 & 0.00 & 45.00 & 15.50 & 26.4532 \\
\hline 17 & 9 & 4.75 & 45.00 & 15.50 & 60.4886 \\
\hline 11 & 10 & 4.75 & 20.00 & 15.50 & 38.1399 \\
\hline 5 & 11 & 1.93 & 30.13 & 21.74 & 38.4142 \\
\hline 4 & 12 & 7.57 & 59.87 & 9.26 & 25.1943 \\
\hline 20 & 13 & 4.75 & 45.00 & 15.50 & 60.4886 \\
\hline 16 & 14 & 4.75 & 45.00 & 15.50 & 60.4886 \\
\hline 8 & 15 & 7.57 & 59.87 & 21.74 & -2.8297 \\
\hline 2 & 16 & 7.57 & 30.13 & 9.26 & 7.3035 \\
\hline 13 & 17 & 4.75 & 45.00 & 5.00 & -1.4465 \\
\hline 6 & 18 & 7.57 & 30.13 & 21.74 & -5.0162 \\
\hline 14 & 19 & 4.75 & 45.00 & 26.00 & 18.5585 \\
\hline 15 & 20 & 4.75 & 45.00 & 15.50 & 60.4886 \\
\hline
\end{tabular}


Table 3 shows the simulation data generated by Design-Expert Software. These experimental design data were simulated in the SolidWorks software, as shown. The combination of $4.75 \%$ camber, $45 \%$ camber location, and 15.50 blade thickness generated the highest torque equivalent to 60.4886 Newton-meter.

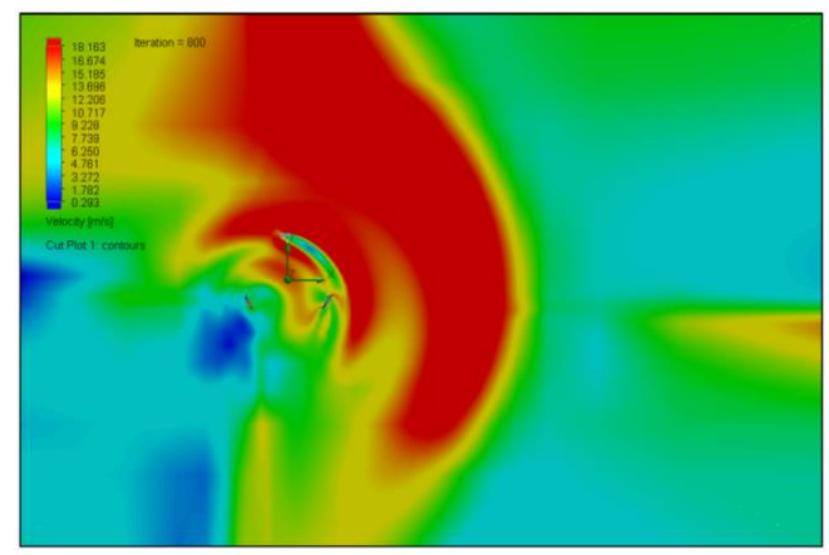

Fig. 4. Sample cut plot of the $3^{\text {rd }} 2 \mathrm{D}$ run simulation.

The 3rd experimental run with values equal to $4.75 \%, 45.00 \%$, and $15.50 \%$ for the Camber, camber location, and thickness, respectively. The simulation generated a 60.4886 $\mathrm{N}-\mathrm{m}$ dynamic torque. This experimental run was replicated on the 6th,9th, 13th, 14th, and 20th.

Table 4. Analysis of Variance (ANOVA) for Response Surface Quadratic Model of 2D Simulation.

\begin{tabular}{|l|l|l|l|l|l|l|}
\hline Source & $\begin{array}{l}\text { Sum of } \\
\text { RreSquares }\end{array}$ & Df & $\begin{array}{l}\text { Mean } \\
\text { Square }\end{array}$ & F Value & $\begin{array}{l}\text { P-value } \\
\text { Prob }>\text { F }\end{array}$ & Remarks \\
\hline Model & 10984.37 & 9 & 1220.49 & 54.60 & $<0.0001$ & Significant \\
\hline A & 742.96 & 1 & 742.96 & 33.24 & 0.002 & Significant \\
\hline B & 82.49 & 1 & 82.49 & 3.69 & 0.0837 & Not \\
\hline C & 195.69 & 1 & 195.69 & 8.75 & 0.0143 & Significant \\
\hline A*B & 41.62 & 1 & 41.62 & 1.86 & 0.2023 & Not \\
\hline A*C & 1218.68 & 1 & 1218.68 & 54.52 & $<0.0001$ & Significant \\
\hline B*C & 29.37 & 1 & 29.37 & 1.31 & 0.2784 & Not \\
\hline$A^{2}$ & 3721.13 & 1 & 3721.13 & 166.47 & $<0.0001$ & Significant \\
\hline$B^{2}$ & 871.72 & 1 & 871.72 & 39.00 & $<0.0001$ & Significant \\
\hline$C^{2}$ & 5458.74 & 1 & 5458.74 & 244.20 & $<0.0001$ & Significant \\
\hline
\end{tabular}

Table 4 showed that the model is significant, with an $\mathrm{F}$ value of 54.60. It means that there was only a $0.01 \%$ chance that a "Model F-value" this large could occur due to noise. Meanwhile, the P-values, which have less than 0.0500 indicate the model terms as significant. Therefore, the $\mathrm{A}, \mathrm{C}, \mathrm{AC}, \mathrm{A}^{2}, \mathrm{~B}^{2}$, and $\mathrm{C}^{2}$ are significant factors. This means that these factors affect the dynamic torque of the blade. The values that are greater than 0.1000 indicate that the model terms are not significant. Mathematically, it is represented below:

Dynamic Torque $=+60.66-7.38 A+2.46 B+3.79 C+2.28 A B-12.34 A B-1.92 B C-16.07 A^{2}-$ $7.78 B^{2}-19.46 C^{2}$

in terms of coded factors and 
Dynamic Torque $=-234.77642+24.92955$ Camber +3.39498 Camber Location +20.33834 Thickness + 0.054328 Camber*Camber Location - 0.69994 Camber*Thickness - 0.020645 Camber

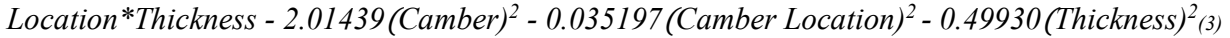

in terms of actual factors.

Equations 2 and 3 are the final regression models in terms of coded and actual factors. The mathematical model simply relates the relationship of the factors and their interactions to the response variable, dynamic torque. The numerical coefficients can be used to assess the impact of every factor directly. Based on the equations, the camber and camber location has a more significant effect on the dynamic torque.

Table 5. Results of the Numerical Optimization of the 2D simulation.

\begin{tabular}{|c|c|c|c|c|c|c|}
\hline Name & Goal & $\begin{array}{c}\text { Lower } \\
\text { Limit }\end{array}$ & $\begin{array}{c}\text { Upper } \\
\text { Limit }\end{array}$ & $\begin{array}{c}\text { Lower } \\
\text { Weight }\end{array}$ & $\begin{array}{c}\text { Upper } \\
\text { Weight }\end{array}$ & Imp. \\
\hline A & is in range & 0 & 9.5 & 1 & 1 & 3 \\
\hline B & is in range & 20 & 70 & 1 & 1 & 3 \\
\hline C & is in range & 5 & 26 & 1 & 1 & 3 \\
\hline $\begin{array}{c}\text { Dynamic } \\
\text { Torque }\end{array}$ & Max & -5.01618 & 60.4886 & 1 & 1 & 5 \\
\hline \multicolumn{7}{|l|}{ Solution } \\
\hline Number & A & B & C & DT & Desirability & \\
\hline 1 & 4.75 & 45.00 & 15.50 & 60.6571 & 1.00 & \\
\hline
\end{tabular}

Table 5 showed the predicted optimal design. The identified factor's optimal values are $4.75 \%$ of the chord, $45.00 \%$ of the chord, and $15.50 \%$ of the chord for camber, camber location, and thickness, respectively. These values generated torque of 60.6571 Newtonmeter. Figure 5 showed the location of the optimal design in comparison to the range of values. It is viewed that the optimal value is within the range of factors.

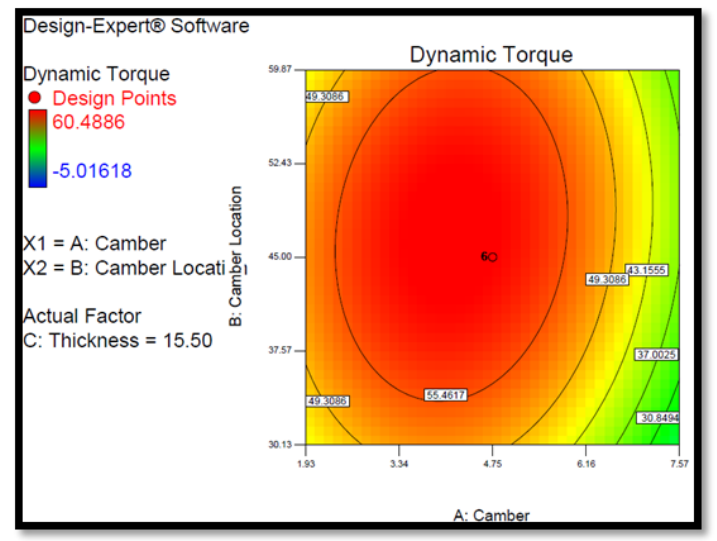

Fig. 5. Response Surface Graph.

\subsubsection{Validation of the 2D Optimization}

Table 6 shows that the optimal values of the factors will generate the same torque at $99.90 \%$. Figures 6 and 7 were produced by the NACA airfoil generator based on the data encoded. Figure 6 was the baseline airfoil for this study. It has zero (0) camber and camber location, with $15 \%$ of the chord's thickness. By varying these previous three (3) parameters, the result is in Figure 7. The optimized airfoil has a camber of $4.75 \%$ of the chord, camber 
location of $45.00 \%$ of the chord, and thickness of $15.50 \%$. This optimized airfoil was used in the $3 \mathrm{D}$ simulation of the blade.

Table 6. Results of Validation of model accuracy.

\begin{tabular}{|c|c|c|c|c|}
\hline \multicolumn{4}{|c|}{ Torques, N-m } \\
\hline $\begin{array}{c}\text { Design Expert } \\
\text { Software }\end{array}$ & \multicolumn{3}{|c|}{ Solidworks Software } & Percent Accuracy \\
\hline Predicted & Run1 & Run2 & Run3 & \\
\hline 60.6571 & 60.1 & 60.5981 & 60.1 & $99.35 \%$ \\
\hline
\end{tabular}

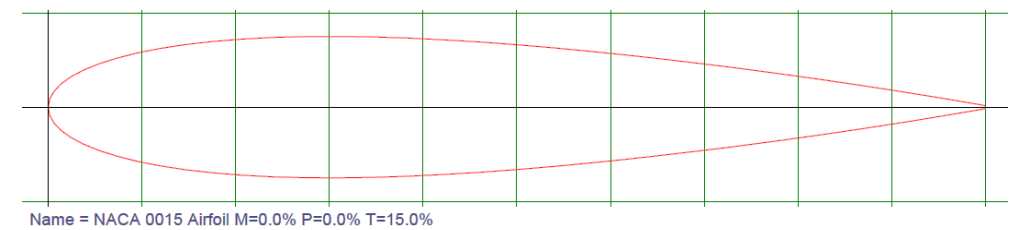

Fig. 6. The NACA 0015 airfoil.

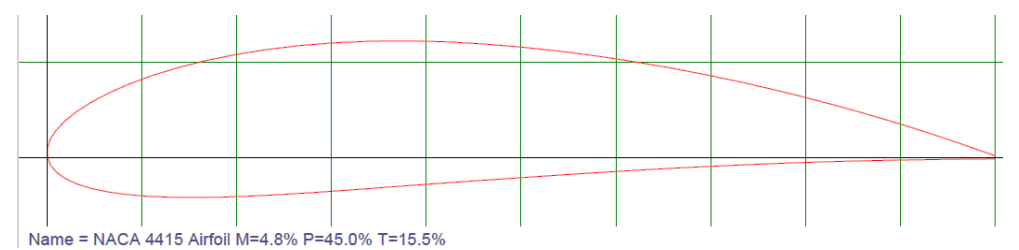

Fig. 7. The Optimized airfoil.

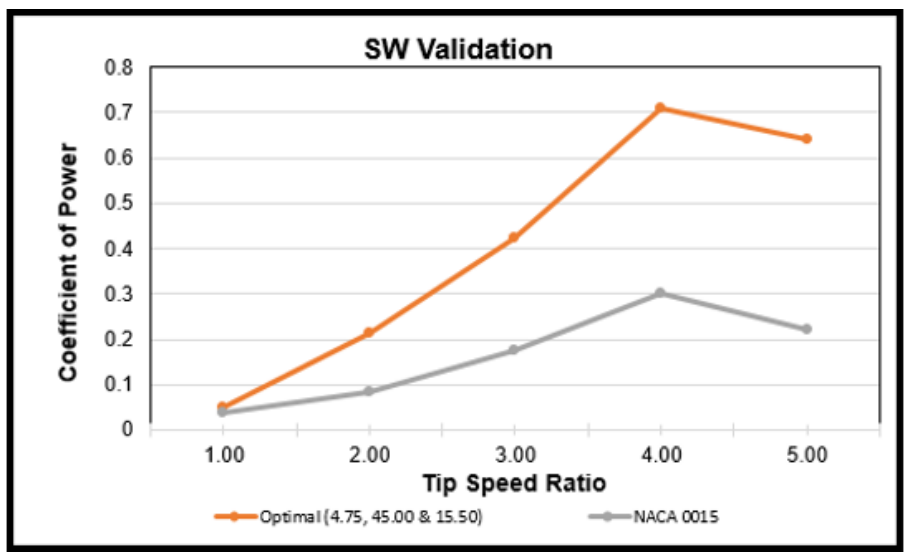

Fig. 8. Comparison of the Optimized Airfoil to the Symmetric Airfoil (NACA 0015).

Figure 8 showed comparison between the NACA 0015 and the optimized design with 4.75 camber, $45 \%$ camber location, and 15.5 thickness. The optimal design's peak coefficient of power is 0.7 while 0.3 for the symmetric airfoil, NACA 0015. Based on this data, there was a 133\% significant increase in the Darrieus Wind Turbine's dynamic torque. The increase in the dynamic torque also increases the performance, power, and efficiency of the turbine. 


\subsection{D optimization of Darrieus wind turbine blade}

Table 7. Results of 3D Simulation.

\begin{tabular}{|c|c|c|c|c|}
\hline & & \multicolumn{2}{|c|}{ Factor } & Response \\
\hline Block & Run & A - Camber (\%) & $\begin{array}{c}\text { B - Camber Location } \\
(\%)\end{array}$ & Dynamic Torque (N-m) \\
\hline 1 & 1 & 4.414 & 4.747 & $2,531.21$ \\
\hline 1 & 2 & 4.414 & 1.919 & 132.93 \\
\hline 1 & 3 & 3.000 & 3.333 & 281.08 \\
\hline 1 & 4 & 3.000 & 3.333 & 281.08 \\
\hline 1 & 5 & 3.000 & 3.333 & 281.08 \\
\hline 1 & 6 & 1.586 & 1.919 & 29.15 \\
\hline 1 & 7 & 3.000 & 3.333 & 281.08 \\
\hline 1 & 8 & 5.000 & 3.333 & 654.04 \\
\hline 1 & 9 & 3.000 & 5.333 & $2,283.57$ \\
\hline 1 & 10 & 3.000 & 1.333 & 44.71 \\
\hline 1 & 11 & 3.000 & 3.333 & 281.08 \\
\hline 1 & 12 & 1.586 & 4.747 & $1,121.29$ \\
\hline 1 & 13 & 1.000 & 3.333 & 58.94 \\
\hline
\end{tabular}

Table 7 showed the simulation data generated by Design-Expert Software. These were simulated in the Solidworks software, as shown. The combination of 4.414 blade height and 4.747 rotor radius generated the highest torque equivalent to 2531.21 Newton-meter. Figure 9 showed surface plot is the $3 \mathrm{rd}$, 4th, 5th, 7th, and 11 th experimental runs with values 3.000 meters and 3.333 meters for the blade height and rotor radius, respectively. It is represented through a cut plot in Figure 9 with a $281.08 \mathrm{~N}-\mathrm{m}$ dynamic torque. 


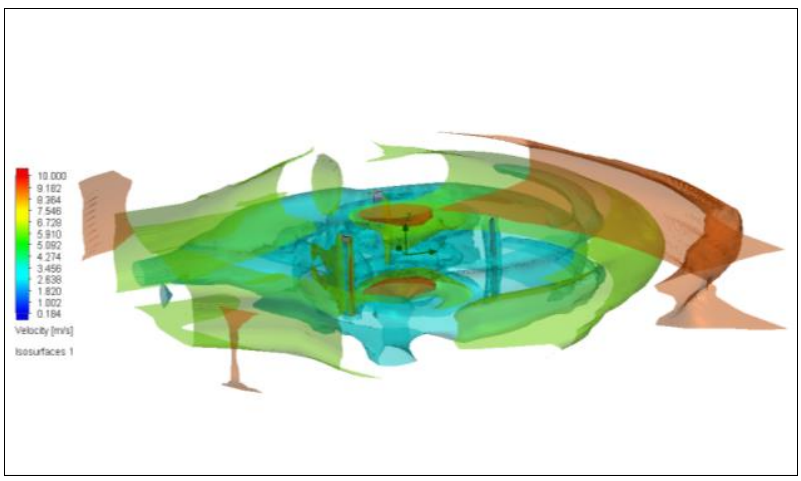

Fig. 9. Surface Plot of the $3^{\text {rd }}, 4^{\text {th }}, 5^{\text {th }}, 7^{\text {th }}$, and $11^{\text {th }} 3 \mathrm{D}$ run simulations.

Table 8. Analysis of Variance for Response Surface Quadratic Model of 3D Simulation.

\begin{tabular}{|l|l|l|l|l|l|}
\hline Source & $\begin{array}{l}\text { Sum of } \\
\text { Squares }\end{array}$ & Mean Square & F Value & $\begin{array}{l}\text { P-value } \\
\text { Prob }>\text { F }\end{array}$ & Remarks \\
\hline Model & $8.332 \mathrm{E}+006$ & $1.666 \mathrm{E}+006$ & 80.80 & $<0.0001$ & Significant \\
\hline $\mathrm{A}$ & $6.934 \mathrm{E}+005$ & $6.934 \mathrm{E}+005$ & 33.63 & 0.0007 & Significant \\
\hline $\mathrm{B}$ & $5.539 \mathrm{E}+006$ & $5.539 \mathrm{E}+006$ & 268.59 & $<0.001$ & Significant \\
\hline $\mathrm{AB}$ & $4.265 \mathrm{E}+005$ & $4.265 \mathrm{E}+005$ & 20.68 & 0.0026 & Significant \\
\hline $\mathrm{A}^{2}$ & 51497.54 & 51497.54 & 2.50 & 0.1581 & Not \\
\hline $\mathrm{B}^{2}$ & $1.669 \mathrm{E}+005$ & $1.669 \mathrm{E}+006$ & 80.95 & $<0.001$ & Significant \\
\hline
\end{tabular}

Table 8 showed that the model is significant, with an $\mathrm{F}$ value of 80.80 . This means that there was only a $0.01 \%$ chance that a "Model F-value" this large could occur due to noise. Meanwhile, the P-values, which have less than 0.0500 , indicated the model terms as significant. Therefore, the $\mathrm{A}, \mathrm{B}, \mathrm{AB}$, and $\mathrm{B} 2$ are significant factors. Values that are greater than 0.1000 indicate that the model terms are not significant. Mathematically, it is represented as follows:

Dynamic Torque $=+281.08+294.41 A+832.08 B+326.53 A B+86.04 A^{2}+489.86 B^{2}$ in terms of coded factor and

Dynamic Torque = 2436.10135 - 594.10721Blade Height -1534.14338 Blade Diameter +163.26738 Blade Height $*$ Rotor Radius +43.01968 (Blade Height) ${ }^{2}+244.93112$ (Rotor Radius) $^{2}$ in terms of actual factors.

Table 9. Results of the 3D Numerical Optimization.

\begin{tabular}{|l|l|l|l|l|l|l|}
\hline \multicolumn{1}{|c|}{ Name } & \multicolumn{1}{|c|}{ Goal } & \multicolumn{1}{c|}{$\begin{array}{c}\text { Lower } \\
\text { Limit }\end{array}$} & $\begin{array}{c}\text { Upper } \\
\text { Limit }\end{array}$ & $\begin{array}{c}\text { Lower } \\
\text { Weight }\end{array}$ & $\begin{array}{c}\text { Upper } \\
\text { Weight }\end{array}$ & Imp. \\
\hline A & is in range & 1.586 & 4.414 & 1 & 1 & 3 \\
\hline B & is in range & 1.919 & 4.747 & 1 & 1 & 3 \\
\hline $\begin{array}{l}\text { Dynamic } \\
\text { Torque }\end{array}$ & Max & 29.15 & 2531.21 & 1 & 1 & 5 \\
\hline \multicolumn{7}{|l|}{ Solution } \\
\hline Number & A & B DT & Desirability & & \\
\hline 1 & 4.41 & 4.75 & 2310.01 & 1.00 & & \\
\hline
\end{tabular}

Table 9 showed the predicted optimal design. The optimal values of the blade height are $4.41 \mathrm{~m}$ and 4.75 for the rotor radius. These values could generate a dynamic torque equivalent to 2310.01 Newton-meter. Figure 10 showed the location of the optimal design 
in comparison to the range of values. It is viewed that the optimal value is within the range of factors.

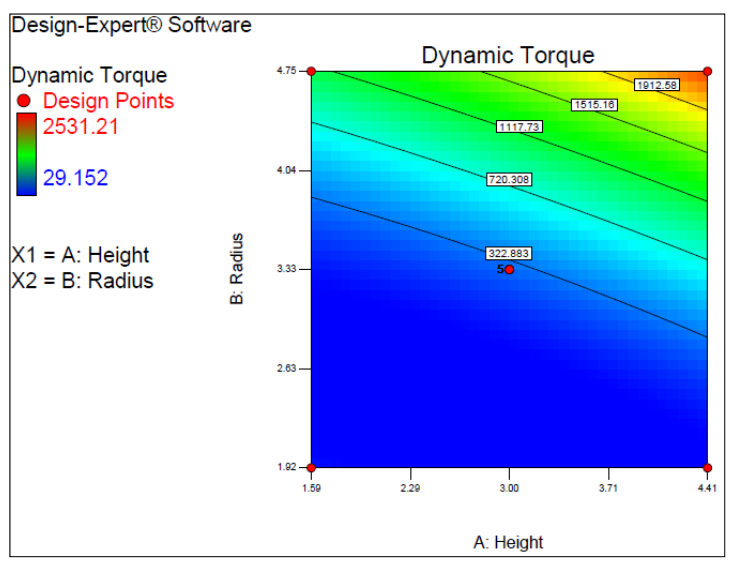

Fig. 10. Response Surface Graph of the 3D Simulation.

\subsubsection{Validation Result of 3D Optimization of the Blade Geometry.}

Table 10 showed that the optimal values of the factors would generate the same torque at $99.92 \%$. Figure 11 was the baseline blade setup of this study. It has a blade height of $3.0 \mathrm{~m}$ and a rotor radius of 3.333. These parameters were varied, and the optimized values of blade height and rotor radius were $4.41 \mathrm{~m}$ and $4.75 \mathrm{~m}$, respectively, as seen in Figure 12.

Table 10. Results of Validation of the Model Accuracy.

\begin{tabular}{|c|c|c|c|c|}
\hline \multicolumn{5}{|c|}{ Torques, N-m } \\
\hline Design Expert Software & \multicolumn{3}{|c|}{ Solidworks Software } & Percent Accuracy \\
\hline Predicted & Run1 & Run2 & Run3 & \\
\hline 2310.01 & 2307.51 & 2308.201 & 2308.9 & 99.92 \\
\hline
\end{tabular}

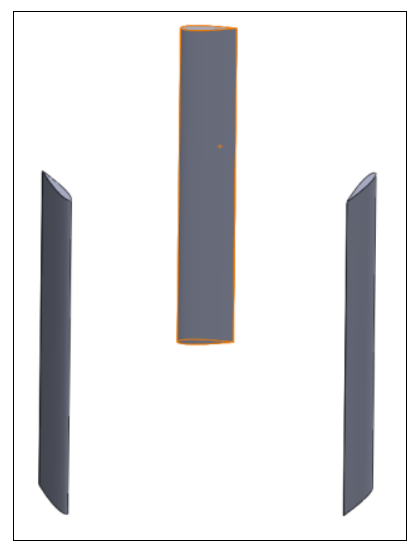

Fig. 11. Blade Setup from the Study of Qamar (2017). 


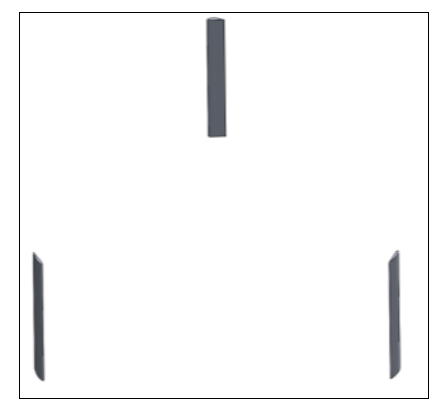

Fig. 12. Optimized Blades of the Darrieus Wind Turbine.

\section{Conclusion}

The Darrieus Wind Turbine Blade's dynamic torque was optimized using the central composite design statistical method and the RANS k-epsilon turbulence model of the Solidworks flow simulation. The study verified that the camber, thickness, interactions, and combinations are significant factors to increase the blade's performance. However, the study proved that the camber location has no significant effect on the airfoil's dynamic torque. The results also proved that the blade height and rotor diameter, their interactions, and the rotor diameter's combination significantly affect the blade performance. The study has proven a significant increase in the performance of the Darrieus Wind Turbine Blade.

\section{Acknowledgement}

This research is funded by the Commission on Higher Education (CHED). The authors further express gratitude to Technological Institute of the Philppines - Quezon City and Romblon State University for the support to finish this study.

\section{References}

1. IEA., Global energy demand grew by $2.1 \%$ in 2017 , and carbon emissions rose for the first, IEA (2018) Retrieved from https://www.iea.org/newsroom/news/2018/march/global-energy-demand-47 grew-by21-in-2018-and-carbon-emissions-rose-for-the-firs.html

2. Kenway, G., \& Martins, J. R. R. A., Aerostructural shape optimization of wind turbine blades considering site-specific winds. 12th AIAA/ISSMO Multidisciplinary Analysis and Optimization Conference, MAO, September (2008) https://doi.org/10.2514/6.2008$\underline{6025}$

3. Aslam Bhutta, M. M., Hayat, N., Farooq, A. U., Ali, Z., Jamil, S. R., \& Hussain, Z., Vertical axis wind turbine - A review of various configurations and design techniques, Renewable Sustainable Energy Rev., 16, 4, 1926-1939 (2012) https://doi.org/10.1016/j.rser.2011.12.004

4. Elliott, D., Schwartz, M., George, R., Haymes, S., Heimiller, D., \& Scott, G. Wind Energy Resource Atlas of the Philippines

5. Khelifi, C., Ouali, M., Ferroudji, F., \& Adjlout, L. Modal Analysis of a Small Savonius Aerogenerator by Using SolidWorks Simulation, Appl. Mech. Mater., 806, 214-221 (2015) https://doi.org/10.4028/www.scientific.net/amm.806.214 
6. Qamar, S. B., \& Janajreh, I. A comprehensive analysis of solidity for cambered darrieus VAWTs, Int. J. Hydrogen Energy, 42, 30, 19420-19431 (2017) https://doi.org/10.1016/j.ijhydene.2017.06.041

7. Islam, M., Ting, D. S. K., \& Fartaj, A., Aerodynamic models for Darrieus-type straightbladed vertical axis wind turbines, Renewable Sustainable Energy Rev., 12, 4, $1087-$ 1109 (2008) https://doi.org/10.1016/j.rser.2006.10.023

8. Jin, X., Zhao, G., Gao, K., \& Ju, W., Darrieus vertical axis wind turbine: Basic research methods, Renewable Sustainable Energy Rev., 42, 212-225 (2015) https://doi.org/10.1016/j.rser.2014.10.021

9. Batista, N. C., Melício, R., Mendes, V. M. F., Calderón, M., \& Ramiro, A., On a selfstart Darrieus wind turbine: Blade design and field tests, Renewable Sustainable Energy Rev., 52, 508-522 (2015) https://doi.org/10.1016/j.rser.2015.07.147

10. Oukassou, K., El Mouhsine, S., El Hajjaji, A., \& Kharbouch, B., Comparison of the power, lift and drag coefficients of wind turbine blade from aerodynamics characteristics of Naca0012 and Naca2412, Procedia Manufacturing, 32, 983-990 (2019) https://doi.org/10.1016/j.promfg.2019.02.312 